\title{
MIR24-2 Pre-miRNA
}

National Cancer Institute

\section{Source}

National Cancer Institute. MIR24-2 Pre-miRNA. NCI Thesaurus. Code C82718.

MIR24-2 pre-miRNA is an olig oribonucleotide that is encoded by the human MIR24-2 gene and is involved in the regulation of gene expression. 